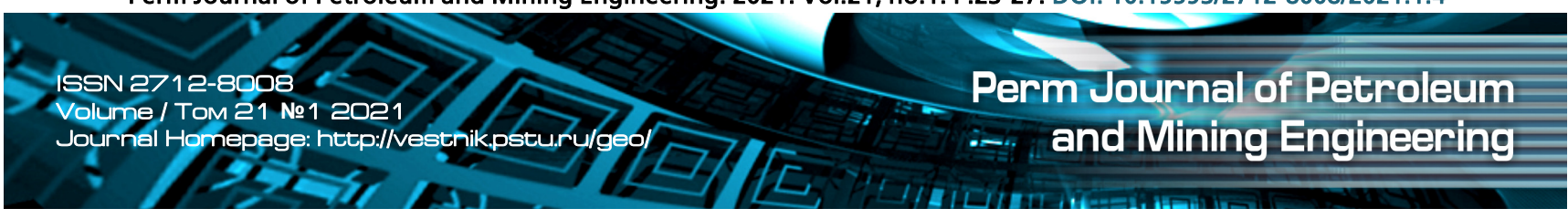

UDC 550.8.023; 519.223.

Article / Статья

(c) PNRPU / ПНИПУ, 2020

\title{
Appearance of Capillary End Effects in Filtration Studies
}

\section{Ivan S. Putilov, Denis B. Chizhov, Evgeniy A. Kochergin}

PermNIPIneft branch of LUKOIL-Engineering LLC in Perm (3a Permskaya st., Perm, 614015, Russian Federation)

Проявление капиллярных концевых эффектов при фрильтрационных исследованиях

\section{И.С. Путилов, Д.Б. Чижов, Е.А. Кочергин}

Филиал ООО «ЛУкОЙЛ-Инжиниринг» «ПермНИПИнефть» в г. Перми (Россия, 614015, г. Пермь, ул. Пермская, 3а)

Received / Получена: 09.04.2020. Accepted / Принята: 02.11.2020. Published / Опубликована: 11.01.2021

Keywords:

relative phase permeabilities, capillary end effects, core, reservoir conditions, pressure drop, reservoir fluids, reservoir oil, reservoir water, fluid saturation, capillary fracture, filtration studies, terrigenous reservoirs, carbonate reservoirs, porosity, gas permeability.
From theoretical studies and experiments on the core, the so-called capillary end effect is known, also called the effect of phases capillary entrapment. When carrying out laboratory experiments to determine the relative phase permeabilities, capillary end effects appear on the core models of the reservoir. These effects can occur as a result of capillary ruptures at the ends of the core sample, which leads to the accumulation of one phase in relation to the other, and thereby affects the movement and retention of the fluid. The region of capillary end effect, which occurs due to the rupture of capillaries at the exit from the sample, affects the change in pressure drop and saturation by a particular fluid. If the influence of capillary end effects is significant, then the experimental conditions are modeled incorrectly, which can lead to serious errors in predicting the productivity of the studied formation.

This paper presents the results of studying the porosity-permeability properties of determining the relative phase permeabilities This paper presents the results of studying the porosity-permeability properties of determining the relative phase permeabilities
and the analysis of the studies of the capillary end effects influence mechanism on the filtration capacity of rock samples during laboratory studies using the example of terrigenous and carbonate types of the Pavlovskoye reservoir. According to the results of the studies, the significance of capillary end effects in filtration experiments was established using the example of determining the relative phase permeabilities. Recommendations are given with the aim of minimizing the negative influence of the end effects. The capillary effects can be overcome by increasing the length of the test sample, as well as by increasing the fluid flow rate during a laboratory experiment to determine the relative phase permeabilities.

Из теоретических исследований и экспериментов на керне известен так называемый капиллярный концевой эффект, или, как его еще называют, эффект капиллярного защемления фаз. При проведении лабораторных экспериментов по определению относительных фазовых проницаемостей на керновых моделях пласта возникают капиллярные концевые эффекты. Данные эффекты могут возникать в результате капиллярных разрывов на концах образца керна, что приводит к накоплению одной фазы по отношению к другой, и тем самым влияют на движение и удержание флюида. Область капиллярного концевого эффекта, которая возникает вследствие разрыва капилляров на выходе из флюида. Область капиллярного концевого эффекта, которая возникает вследствие разрыва капилляров на выходе из влияние капиллярных концевых эффектов будет значительным, то условия проведения эксперимента моделируются неверно, что может привести к серьезным ошибкам при прогнозировании производительности изучаемого пласта.

Представлены результаты изучения фильтрационно-емкостных свойств определения относительных фазовых проницаемостей и анализ исследований механизма влияния капиллярных концевых эффектов на фильтрационную способность образцов горных пород во время проведения лабораторных исследований на примере терригенного и карбонатного типов коллектора Павловского месторождения. По результатам проведенных исследований установлена значимость капиллярных концевых эффектов при фильтрационных экспериментах на примере определения относительных фазовых проницаемостей. Даны рекомендации с целью максимального снижения отрицательного влияния концевых эффектов. Капиллярные эффекты могут преодолеваться путем увеличения длины исследуемого образца, а также с помощью возрастания расхода флюида в процессе проведения лабораторного эксперимента по определению относительных фазовых проницаемостей.

Ivan S. Putilov (Author ID in Scopus: 25723777700) - Doctor in Engineering, Deputy Director of the Branch for Scientific Work in the Field of Geology (tel.: + 00734223364 58, e-mail: Ivan.putilov@pnn.lukoil.com).

Denis B. Chizhov (Author ID in Scopus: 57112213900) - Head of the Department for Special Research of Core and Reservoir Fluids (tel.: + 0073422336500 , e-mail: Denis.Chizhov@pnn.lukoil.com). The contact person for correspondence.

Evgeniy A. Kochergin - 1st category Engineer at the Department of Physical and Hydrodynamic Research (tel.: + 00734271701 54, e-mail: Evgenij.Kochergin@pnn.lukoil.com).

Путилов Иван Сергеевич - заместитель директора филиала по научной работе в области геологии, доктор технических наук (тел.: +007 3422336458 , e-mail: Ivan.Putilov@pnn.lukoil.com).

Чижов Денис Борисович - начальник управления специальных исследований керна и пластовых флюидов (тел.: +007 3422336500 , e-mail: Denis.Chizhov@pnn.lukoil.com). Контактное лицо для переписки.

Кочергин Евгений Александрович - инженер I категории отдела физико-гидродинамических исследований (тел.: + 0073427170154 , e-mail: Evgenij.Kochergin@pnn.lukoil.com).

Please cite this article in English as:

Putilov I.S., Chizhov D.B., Kochergin E.A. Appearance of Capillary end Effects in Filtration Studies. Perm Journal of Petroleum and Mining Engineering, 2021, vol.21, no.1, pp.23-27. DOI: 10.15593/2712-8008/2021.1.4

Просьба ссылаться на эту статью в русскоязычных источниках следующим образом:

Путилов И.С., Чижов Д.Б., Кочергин Е.А. Проявление капиллярных концевых эффектов при фильтрационных исследованиях // Недропользование. - 2021. T.21, №1. - C.23-27. DOI: $10.15593 / 2712-8008 / 2021.1 .4$ 


\section{Introduction}

Liquids inside oil reservoirs move around along extremely complicated systems of branching out pore channels that vary in size. THEREFORE a joint stream of two immiscible liquids, like oil and water, are marked by a vast, extremely curved interface surface that is affected by surface forces. Each of the phases moves within its system of pore channels maintaining continuity; however, at times a fluid particle can get into the channel filled with a different phase. It happens at high gradients of pressure [1].

There is theoretical and experimental evidence of the so-called capillary end effect, which is also known as the effect of capillary entrapment of phases. It is caused by the physical condition of continuity of pressures in phases both inside the porous medium and at the contact of two spans of the porous medium. Since pressures within phases are continuous, consequently, the capillary pressure should be continuous throughout the entire two-phase span.

This effect can be found around the contact of two spans of porous medium with different capillary properties. In this case the saturation of wetting phase changes around the boundary to a value that equalizes capillary pressures.

The end effect impact zone spans along the entire length of the complex model and can significantly affect the results of laboratory studies [2].

This article attempts to identify the capillary end effects in laboratory conditions, determine their significance and analyze their impact using filtration studies in reservoir conditions, namely, based on the determination of phase permeabilities.

Phase permeability is one of the most important parameters characterizing the reservoir fluid distribution process in oil and gas reservoir rock. Data on phase permeability are necessary for justifying saleable limits, petrophysical properties of rocks when making an industrial estimate of transient oil- and gas-bearing zones in the strata, gas-hydrodynamic calculations of technological indexes when choosing a method of impact on the stratum for enhanced oil recovery, as well as field development analysis and control.

\section{Conducted Studies}

1. Selection and preparation of samples for filtration studies.

In order to identify and then estimate and compare the impact of capillary end effects depending on lithology and various degrees of heterogeneity, the study considered samples of the core from two lithologically different layers: Tournaisian (carbonate) and Visean (terrigenous) deposits. The samples were collected from two wells with high reservoir properties (Table 1).

The samples were sawed to the size of $80 \times 30 \mathrm{~mm}$ oriented parallel to the layering (Fig. 1), and then prepared for filtration studies.

The core samples were washed in alcohol-benzene mixture to remove oil and bitumens using extraction in the Soxlet apparatus and dried in the cabinet to the fixed weight. Further, samples were characterized in terms of their reservoir properties: absolute gas permeability factor and connected porosity factor (Table 2).

The samples were then saturated with the reservoir water model that was basically a mineralized solution of $\mathrm{NaCl}$ with concentration of $234 \mathrm{~g} / \mathrm{l}$. The samples were weighed to calculate their pore volume.

After reservoir properties were determined, the prepared samples were placed inside the filtration unit (Fig. 2) which simulated the reservoir conditions and housed the

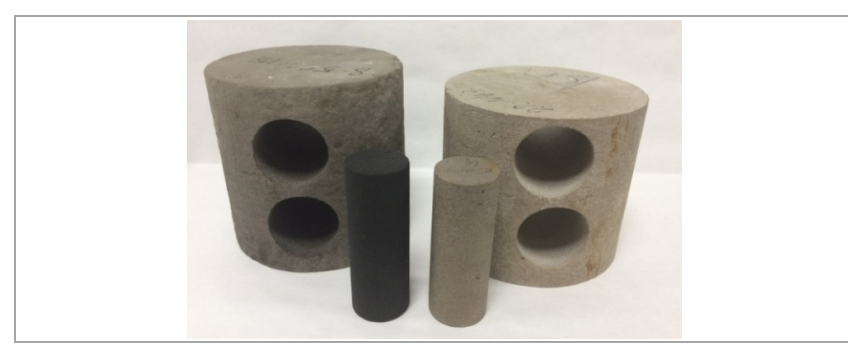

Fig. 1. Sawed samples

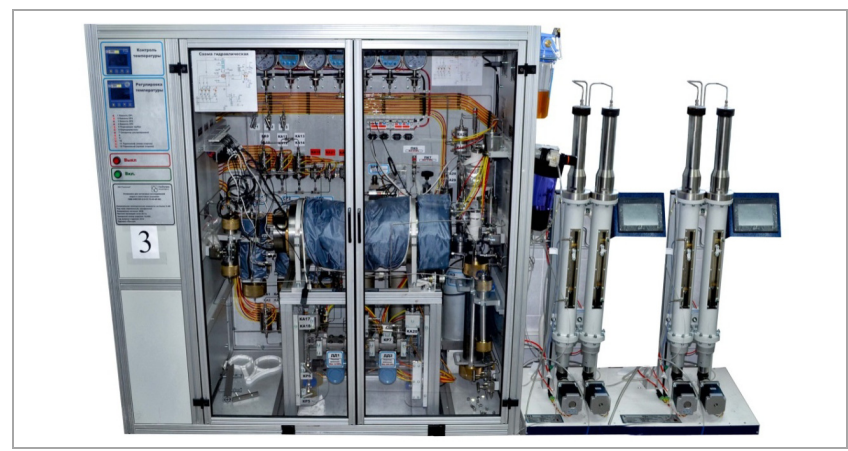

Fig. 2. Filtration unit ПИК-ОФП-2-1-4-СУ-70-40-АР-ЭС

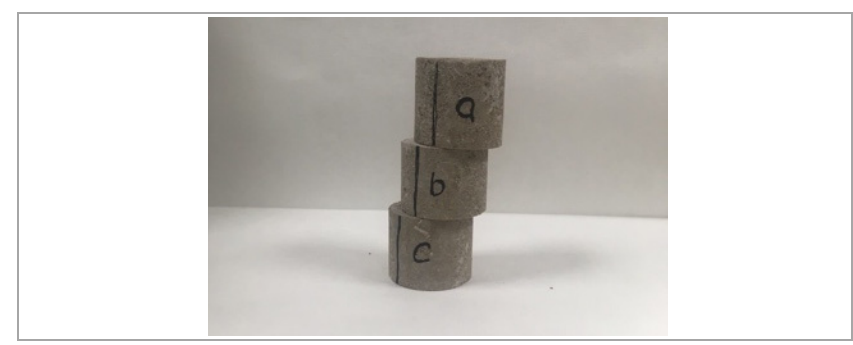

Fig. 3. Composite sample model after repeat treatment

experiments. The studies were conducted in the simulated reservoir conditions at the temperature of $25{ }^{\circ} \mathrm{C}$ and under effective pressure of $5 \mathrm{MPa}$.

The studies featured the following fluids:

a) reservoir water model that was used to saturate the samples and determine the permeability coefficient to water $\left(K_{\mathrm{pw} 1}\right)$;

b) isoviscous model of the Pavlovskoye field oil that was used to create the initial water saturation and determine the phase permeability to oil $\left(K_{\mathrm{po}}\right)$;

c) fresh water that was used as a displacement agent and to measure the phase permeability to water $\left(K_{\mathrm{pw} 2}\right)$.

Residual water saturation was generated by means of displacement in the filtration unit in reservoir conditions.

The fluid parameters are given in Table 3.

2. Studies conducted using samples $80 \times 30 \mathrm{~mm}$ in size.

Filtration testing started with measuring permeability to reservoir water. The reservoir water was filtrated step by step, at 5 different flow rates, to the point of stabilization of differential pressure but not less than 3 porous volumes.

The prepared sample was then put through tests to determine steady-state filtration using the relative phase permeability (RPP) method in accordance with OST 39-235-89 in conditions that are as close to the reservoir reality as possible. Fluids (oil, water) were injected in various modes. In each mode, the fluids were injected up to the point of stabilization of differential pressure, resistance, and ratio of injected and displaced phase volumes [3].

At the end of the experiment permeability was measured to displacement agent in the sample with residual oil saturation (Table 4). 
Core samples for the research

\begin{tabular}{|c|c|c|c|c|c|c|}
\hline Field & $\begin{array}{l}\text { Sample } \\
\text { number }\end{array}$ & Age & Depth, m & Lithologic description & $\begin{array}{l}\text { Gas permeability, } \\
\qquad 10^{-3} \mu \mathrm{m}^{2}\end{array}$ & $\begin{array}{l}\text { Porosity, } \\
\quad \%\end{array}$ \\
\hline Pavlovskoye & $22-448-14$ & $\mathrm{C}_{1} \mathrm{t}$ & 1459.31 & $\begin{array}{l}\text { Brown limestone, oil-saturated, highly porous, } \\
\text { with fine caverns formed around organic remains, solid }\end{array}$ & 385.96 & 18.30 \\
\hline Pavlovskoye & 8-599-15 & $\mathrm{C}_{1} \mathrm{tl}_{\mathrm{T}}$ & 1433.15 & $\begin{array}{l}\text { Dark brown sandstone, intensely oil-saturated, fine-grained, } \\
\text { with singular grains of medium size, highly porous, solid }\end{array}$ & 428.98 & 20.11 \\
\hline
\end{tabular}

Reservoir properties of samples

Table 2

\begin{tabular}{cccccccc}
\hline $\begin{array}{c}\text { Sample } \\
\text { number }\end{array}$ & $\begin{array}{c}\text { Reservoir } \\
\text { type }\end{array}$ & $\begin{array}{c}\text { Length } L, \\
\mathrm{~cm}\end{array}$ & $\begin{array}{c}\text { Diameter } D, \\
\mathrm{~cm}\end{array}$ & $\begin{array}{c}\text { Porosity, } \\
\%\end{array}$ & $\begin{array}{c}\text { Gas permeability, } \\
10^{-3} \mu \mathrm{m}^{2}\end{array}$ & $\begin{array}{c}\text { Pore } \\
\text { volume, } \mathrm{cm}^{3}\end{array}$ & $\begin{array}{c}\text { Residual water } \\
\text { saturation, u.f. }\end{array}$ \\
\hline $22-448-14$ & Carbonate & 8.02 & 2.95 & 18.61 & 376.15 & 11.76 \\
\hline $8-599-15$ & Terrigenous & 7.82 & 2.91 & 20.99 & 411.13 & 0.120 \\
\hline
\end{tabular}

Table 3

Fluid parameters

\begin{tabular}{|c|c|c|c|c|}
\hline \multicolumn{2}{|c|}{ Fluid } & Viscosity in reservoir conditions, $\mathrm{mPa} \cdot \mathrm{s}$ & Density, $\mathrm{g} / \mathrm{cm}^{3}$ & Temperature, ${ }^{\circ} \mathrm{C}$ \\
\hline Reservoir $\mathrm{w}$ & & 1.56 & 1.146 & 25 \\
\hline \multirow{3}{*}{ Oil model } & Terrigenous reservoir & 3.38 & 0.828 & 25 \\
\hline & Carbonate reservoir & 3.51 & 0.835 & 25 \\
\hline & & 1.00 & 1.00 & 25 \\
\hline
\end{tabular}

Measurement of permeability to displacement agent

Table 4 Permeability coefficient, $10^{-3} \mu \mathrm{m}^{2}$

\begin{tabular}{ccccc}
\hline \multirow{2}{*}{ Reservoir type } & \multicolumn{3}{c}{ Permeability coefficient, $10^{-3} \mu \mathrm{m}^{2}$} \\
\cline { 2 - 5 } & to gas & to water $234 \mathrm{~g} / 1$ & to oil at residual water saturation & to water at residual oil saturation \\
\hline Terrigenous & 411.13 & 340.76 & 82.49 & 11.51 \\
\hline Carbonate & 376.15 & 303.90 & 64.55 & 10.09 \\
\hline
\end{tabular}

\section{Repeat treatment.}

After completing the filtration tests using the core of $80 \times 30 \mathrm{~mm}$, the samples went through the repeat treatment that included the following:

- extraction (removal of oil and bitumens from the rock);

- sawing of the $80 \times 30 \mathrm{~mm}$ core into three identical samples;

- determination of reservoir properties of the samples.

The repeat treatment resulted in the formation of composite models (Fig. 3).

The results of reservoir properties are presented in Table 5.

4. Conducted studies with composite models.

Filtration tests were carried out using the same technique as in Procedure 2. The results of laboratory tests are presented in Table 6.

\section{Analysis of Filtration Test Results}

The results of the laboratory tests were compiled into tables for comparison, graphs were drawn to make conclusions about the role of end effects on reservoir properties of rocks.

The capillary end effect results from erupting capillars on the way out of the sample, which leads to accumulation of one phase in relation to another and affects the measurement of differential pressure and saturation in the experiment aimed at determining phase permeabilities.

The results of tests are given in Table 7 to compare reservoir properties and saturation of the $80 \times 30 \mathrm{~mm}$ samples and composite models after the repeat treatment.

When comparing saturation, it is necessary to identify an increase in water saturation and a drop in oil saturation in composite models. For example, a solid carbonate-type sample in the mode of $50 \%$ water with $50 \%$ of oil demonstrates water saturation at 0.41 u.f., whereas a composite model is at 0.56 u.f. This confirms the presence of capillary end effects during filtration tests.

At the beginning of studies, absolute permeability was measured on the reservoir water model using solid samples
$80 \times 30 \mathrm{~mm}$ in size, which were then sawed into three approximately identical samples to measure permeability using the composite model. The measurements were made at various flow rates (Fig. 4, 5).

The results in the graphs suggest that absolute permeability of the composite model be lower than that of the solid $80 \times 30 \mathrm{~mm}$ sample. It is worth noting that the terrigenous sample shows a minor decrease to $17 \%$ in comparison with the carbonate sample where it can drop by as much as $40 \%$. This decrease in permeability is due to the erupting capillars on the way out of the sample, which results in one phase building up in relation to another and affects the measurements of differential pressure and saturation.

Another important observation is that at higher fluid filtration rates the impact of capillary effects is reduced.

After conducting the experiment on determination of RPP, it can be concluded that phase permeabilities to the composite model are lower than those to the solid sample, which further confirms the impact of capillary end effects. Comparing the terrigenous reservoir in the solid and composite samples, there are slight deviations of relative permeabilities and water cuts (Fig. 5, a). The carbonate type showed more pronounced deviations: the composite sample had higher actual water saturation, while oil saturation was lower at every step of the experiment in comparison with the solid sample (Fig. 5, b).

\section{Conclusion}

The analysis of results obtained in the studies confirmed manifestation of capillary end effects that occur on the butts of certain composite model samples, namely:

- the comparison of saturation values showed an increase in water saturation and a decrease in oil saturation in composite models;

- the comparison of permeabilities revealed a drop in permeability in composite samples.

It is also found that at higher fluid filtration rates the impact of capillary effects is reduced. 
Table 5

Resulting porosity and permeability properties

\begin{tabular}{|c|c|c|c|c|c|c|c|c|}
\hline Field & Reservoir type & $\begin{array}{l}\text { Sampl } \\
\text { e no. }\end{array}$ & $L, \mathrm{~cm}$ & $D, \mathrm{~cm}$ & $K_{\mathrm{p}}, \%$ & $\begin{array}{c}K_{\mathrm{p}} \text { to gas, } \\
10^{-3} \mu \mathrm{m}^{2}\end{array}$ & $\begin{array}{l}\text { Pore volume, } \\
\mathrm{cm}^{3}\end{array}$ & $\begin{array}{c}\text { Residual } \\
\text { water saturation, u.f. }\end{array}$ \\
\hline \multirow{6}{*}{ Pavlovskoye } & \multirow{3}{*}{ Terrigenous } & $\mathrm{a}$ & 2.46 & 2.91 & 21.0 & 504.9 & 3.41 & \multirow{3}{*}{0.28} \\
\hline & & $\mathrm{b}$ & 2.30 & 2.91 & 21.02 & 486.0 & 3.21 & \\
\hline & & $\mathrm{c}$ & 2.60 & 2.91 & 21.05 & 458.7 & 3.58 & \\
\hline & \multirow{3}{*}{ Carbonate } & $\mathrm{a}$ & 2.82 & 2.94 & 18.02 & 396.5 & 3.30 & \multirow{3}{*}{0.14} \\
\hline & & $\mathrm{b}$ & 2.33 & 2.95 & 18.53 & 476 & 2.82 & \\
\hline & & $\mathrm{c}$ & 2.43 & 2.95 & 18.06 & 383.3 & 2.91 & \\
\hline
\end{tabular}

Laboratory test results

Table 6

\begin{tabular}{ccccc}
\hline \multirow{2}{*}{ Reservoir type } & \multicolumn{4}{c}{ Permeability coefficient, $10^{-3} \mu^{2}$} \\
\cline { 2 - 5 } & to gas & to water $234 \mathrm{~g} / \mathrm{l}$ & to oil at residual water saturation & to water at residual oil saturation \\
\hline Terrigenous & 483.20 & 315.69 & 53.87 & 10.23 \\
\hline Carbonate & 418.60 & 255.43 & 21.25 & 3.67 \\
\hline
\end{tabular}

Test results

Table 7

\begin{tabular}{|c|c|c|c|c|c|c|c|}
\hline Reservoir type & $L, \mathrm{~cm}$ & $D, \mathrm{~cm}$ & $K_{\mathrm{p}}, \%$ & $\begin{array}{l}K_{\mathrm{p}} \text { to gas, } \\
10^{-3}{\mu \mathrm{m}^{2}}^{2}\end{array}$ & $\begin{array}{c}\text { Pore } \\
\text { volume, } \\
\mathrm{cm}^{3}\end{array}$ & $\begin{array}{c}\text { Residual } \\
\text { water saturation, u.f. }\end{array}$ & $\begin{array}{c}\text { Residual } \\
\text { oil saturation, u.f. }\end{array}$ \\
\hline Terrigenous (solid) & 7.82 & 2.91 & 20.99 & 411.13 & 12.59 & 0.27 & 0.35 \\
\hline Terrigenous (composite) & 7.34 & 2.91 & 21.02 & 483.2 & 10.2 & 0.28 & 0.31 \\
\hline Carbonate (solid) & 8.02 & 2.95 & 18.61 & 376.15 & 11.76 & 0.12 & 0.40 \\
\hline Carbonate (composite) & 7.58 & 2.95 & 18.61 & 418.6 & 9 & 0.14 & 0.28 \\
\hline
\end{tabular}
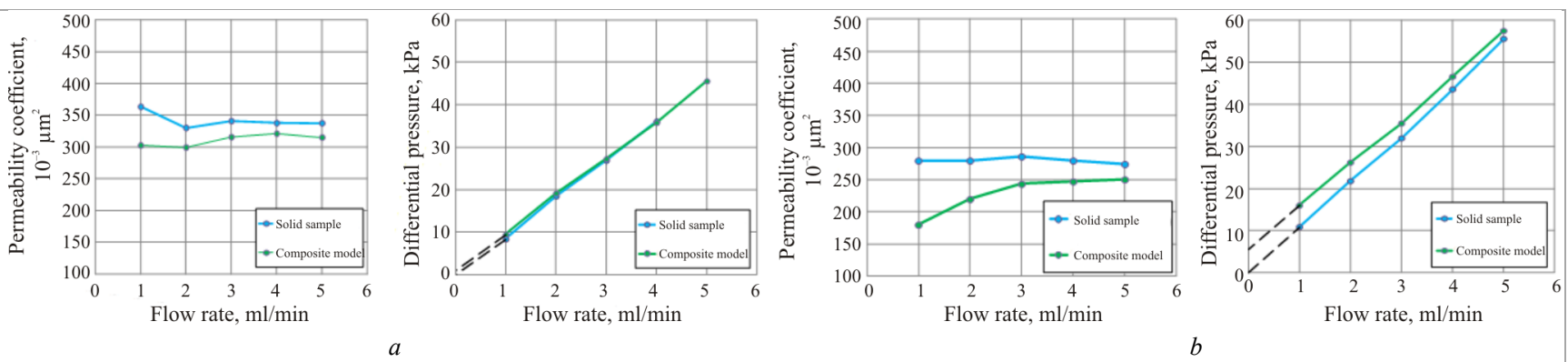

Fig. 4. Graphs of dependence of the absolute permeability coefficient and differential pressure on a certain flow rate: $a$ - for the terrigenous sample; $b$-for the carbonate sample
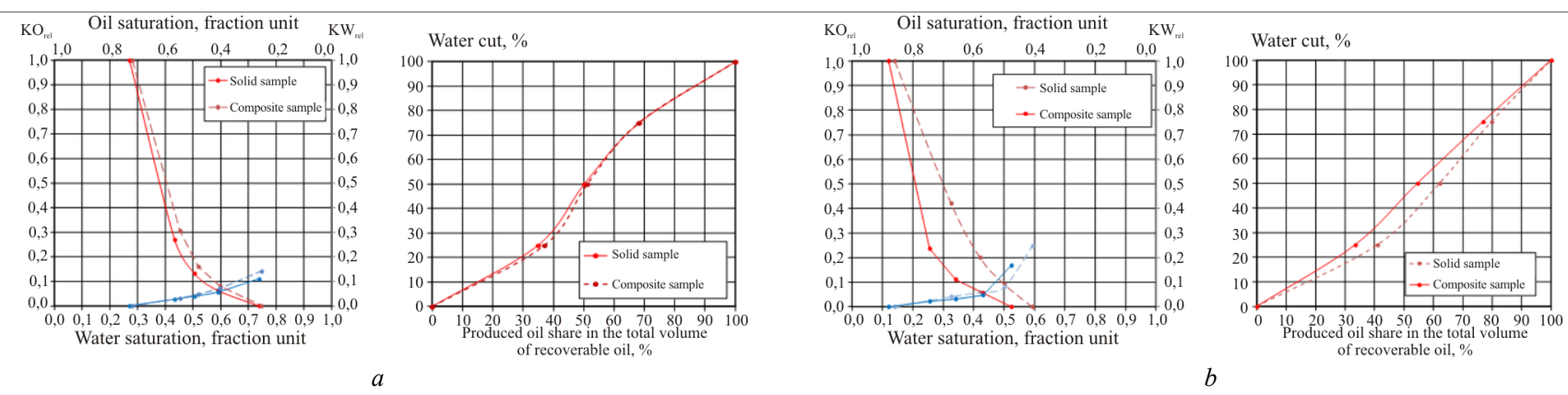

Fig. 5. RPP graphs and dependence of water cut on the displaced volume: $a-$ for the terrigenous sample; $b$ - for the carbonate sample

The laboratory experiments on the determination of relative phase permeations shown in graphs demonstrate deviations of permeabilities and actual fluid saturations as they relate to the solid and composite samples. The biggest differences are identified in carbonate samples. It further confirms the impact of capillary fractures at the sample butts on the flow and retention of fluids. Should this impact or the end effect defect be considerable, the results of the laboratory tests are deemed to be wrong, which may lead to grave errors in forecasting the stratum operation. Subsequently it is important to consider the manifestation of capillary end effects in filtration tests.

\section{References}

1. Mirchink M.F., Mirzadzhanzade A.Kh., Zheltov Iu.V. et al. Fiziko-geologicheskie problemy povysheniia neftegazootdachi plastov [Physico-geological problems of

2. Shupik N.V. Povyshenie effektivnosti ploshchadnykh sistem zavodneniia nizkopronitsaemykh plastov Zapadnoi Sibiri [Improving the efficiency of areal waterflooding 2. Shupik N.V. Povyshenie effektivnosti ploshchadnykh sistem zavodneniia nizkopronitsaemykh pla

systems for low-permeability formations in Western Siberia]. Moscow: IPNGRAN, 2017, pp. 24-28.
3. OST 39-235-89. Neft'. Metod opredeleniia fazovykh pronitsaemostei v laboratornykh usloviiakh pri sovmestnoi statsionarnoi fil'tratsii [OST 39-235-89. Oil. Method for determining phase permeabilities in laboratory conditions with joint stationary filtration]. Moscow, $1989,29 \mathrm{p}$.

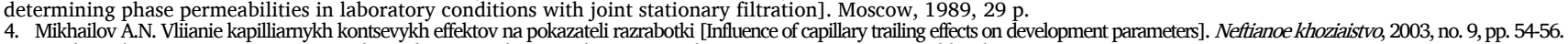

4. Mikhailov A.N. Vliianie kapilliarnykh kontsevykh effektov na pokazateli razrabotki [Influence of capillary trailing effects on development parameters]. Neftianoe khoziaistvo, 2003 , no. 9, pp. 54-56.

6. OST 39-195-86. Neft'. Metod opredeleniia koeffitsienta vytesneniia nefti vodoi v laboratornykh usloviiakh [OST 39-195-86. Oil. Method for determining the coefficient 6. OST 39-195-86. Neft'. Metod opredeleniia koeffitsienta vytesneniia nefti vodo
of oil displacement by water in laboratory conditions]. Moscow, 1986, 20 p.

7. Mikhailov N.N. Ostatochnoe neftenasyshchenie razrabatyvaemykh plastov [Residual oil saturation of developed reservoirs]. Moscow: Nedra, $1992,270 \mathrm{p}$.

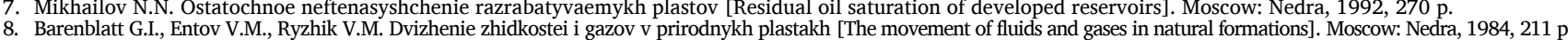

9. Gumatudinov Sh.K., Shirkovskii A.I. Fizika neftenogo i gazovogo plasta [Physics of oil and gas reservoir]. Moscow: Nedra, 1982, 311 p. 
10. Ivanova M.M., Mikhailov N.N., Iaremiichuk R.S. Regulirovanie fil'tratsionnykh svoistv plasta v okoloskvazhinnykh zonakh [Controlling the filtration properties of the formation in the near-wellbore zones]. Moscow: VNIIOENG, 1988

11. Mirzadzhanzade A.Kh., Kuznetsov O.L., Basniev K.S., Aliev Z.S. Osnovy tekhnologii dobychi gaza [Gas production technology basics]. Moscow: Nedra, 2003, 880 p. 12. Pirverdian A.M. Fizika i gidravlika neftianogo plasta [Physics and Hydraulics of Oil Reservoir]. Moscow: Nedra, 1982, $192 \mathrm{p}$.

13. Romm E.S. Strukturnye modeli porovogo prostranstva gornykh porod. [Structural models of the pore space of rocks]. Leningrad: Nedra, $1985,240 \mathrm{p}$.

14. Jodry R.L., Cinilingarian G.V., Mazzuiloand S.J., Rieke H.H. Chapter 6 Pore Geometry of Carbonate Rocks and Capillary Pressure Curves (Basic Geologic Concepts), Carbonate Reservoir Characterization: A Geologic-Engineering Analysis. Part I. Elsevier, Amsterdam, Vol. 30, 1992, P. 331-377. DOI: 10.1016/S0376-7361(09)70129-3 15. Skopec RA. Proper Coning and Wellsite CoreHandling Procedures: The First Step Toward Reliable Core Analysis. Joumal of Petroleumn Technology. April 1994, vol. 46, iss. 04, pp. 280-280. DOI: 10.2118/28153-PA 16. Chilingarian G.V., Mazzullo S.J., Rieke H.H. Carbonate reservoir characterization: a geologic-engineering analysis, part 2. Elsevier, 1996, 993 p.

17. Denney D. Whole Core vs. Plugs: Integrating Log and Core Data to Decrease Uncertainty in Petrophysical Interpretation and Oil-In-Place Calculations. Journal of Petroleum Techology, 2011, vol. 63, SPE. No. 0811-0058-JPT, pp. 58-60. DOI. 10.2118/0811-0058-JPT

18. Herrera R.G., Fernando S.V., Hernandez F.P. On the Petrophysics of Carbonate Reservoirs Through Whole Cole Analysis. Society of Petroleum Engineers, International Petroleum Conference and Exhibition of Mexico, 10-13 October 1994. Veracruz, Mexico. DOI: 10.2118/28675-MS

19. Johnson N.L., Leone F.C. Statistics and experimental design. New York - London - Sydney - Toronto, 1977, 606 p.

20. Montgomery D.C., Peck E.A. Introduction to liner regression analysis. New York: John

22. Yarus J.M. Stochastic modeling and geostatistics. AAPG. Tulsa, Oklahoma, 1994, $231 \mathrm{p}$

23. Indrupskii I.M., Iastrebkova K.A., Shupik N.V. Modelirovanie tekhnologicheskikh rezhimov raboty skvazhin razlichnogo tipa v nedonasyshchennykh kollektorakh Zapadnoi Sibiri s uchetom kapilliarnogo kontsevogo effekta [Modeling technological modes of operation of wells of different types at undersaturated reservoirs of Western Siberia taking into account the capillary and effect]. Mezhdunaronaia konferentsiia “Tiumen'-2005. Glubokie gorizonty nauki i nedr" Tiumen', 2015.

24. Indrupskii I.M. Uchet kapilliarno uderzhivaemoi vody pri modelirovanii dvukhfaznoi filtratsii v laboratornykh iplastovykh usloviiakh [Taking into account capillary retained water when modeling two-phase filtration in laboratory and reservoir conditions]. Avtomatizatsiia, telemekhanizatsiia i sviaz'v neftianoi promyshlennosti, 2009 , no. 11, pp. 45-53. 25. Zakirov S.N., Indrupskii I.M., Zakirov E.S., Zakirov I.S. et al. Novye printsipy i tekhnologii razrabotki mestorozhdenii nefti i gaza. Chast' 2 [New principles and technologies for the development of oil and gas fields. Part 2]. Moscow, Izhevsk: Institut kompiuternykh issledovanii, 2009, 484 p.

26. Iastrebkova K.A. Modelirovanie vliianiia kapilliarnykh effektov na nachal'nuiu obvodnennost' skvazhin v nedonasyshchennykh plastakh [Modeling the influence of capillary effects on the initial water cut of wells in undersaturated reservoirs

27. Shupik N.V. Vliianie kapilliarnykh kontsevykh effektov na rabotu skvazhin razlichnogo tipa v nedonasyshchennykh kollektorakh [Capillary end effect of wells 28. Orlov D.M., Ryzhov A.E., Perunova T.A. Metodika opredeleniia otnositel'nykh fazovykh pronitsaemostei po dannym nestatsionarnoi fil'tratsii putem sovmestnogo fizicheskogo i komp'iuternogo modelirovaniia [Method for determining relative phase permeabilities from non-stationary filtration data by joint physical and computer modeling]. Prikladnaia mekhanika i tekhnicheskaia fizika, 2013, no. 5, pp. 119-128.

29. Efros D.A. Issledovanie fil'tratsii neodnorodnykh sistem [Investigation of filtration of heterogeneous systems]. Moscow: Gostoptekhizdat, 1963 , 349 p.

30. Shchelkachev V.N. Osnovy podzemnoi neftianoi gidravliki [Fundamentals of underground oil hydraulics]. Moscow: Gostoptekhizdat, 1945.

31. Kheifets L.I., Neimark A.V. Mnogofaznye protsessy v poristykh sredakh [Multiphase processes in porous media]. Moscow: Khimiia, 1982.320 p.

32. Kolesnik S.V., Trofimov A.S., Polishchuk S.T. Otnositel'naia fazovaia pronitsaemost' [Relative phase permeability]. Tiumen': Tiumenskii gosudarstvennyi neftegazovyi universitet, 2013, $96 \mathrm{p}$.

33. Kadet V.V., Khurgin Ia.I. Sovremennye veroiatnostnye podkhody pri reshenii zadach mikro- i makrourovnia v neftegazovoi otrasli [Modern probabilistic approaches to solving problems at the micro and macro levels in the oil and gas industry]. Moscow, Izhevsk: Institut komp'iuternykh issledovanii, NITs "Reguliarnaia i khaoticheskaia dinamika", 2006,240 p. 34. Loitsianskii L.G. Mekhanika zhidkosti i gaza [Fluid and Gas Mechanics]. Moscow, Leningrad: Gosudarstvennoe izdatel'stvo tekhniko-teoreticheskoi literatury, 1950, 678 p. 35. Masket M. Fizicheskie osnovy tekhnologii dobychi nefti [Physical foundations of oil production technology]. Moscow, Izhevsk: Institut komp'iuternykh issledovanii, 2004 , 606 p. 36. Syrtlanov V.R., Fatikhov S.Z. O podkhode k remasshtabirovaniiu otnositel'nykh fazovyk

37. Shagapov V.Sh. O fil'tratsii gazirovannoi zhidkosti [About carbonated liquid filtration]. Prikladnaia mekhanika i tekhnicheskaia fizika, 1993, no. 5, pp. 97-106.

38. Shagapov V.Sh., Syrtlanov V.R. Filtratsiia kipiashchei zhidkosti v poristoi srede [Filtration of boiling liquid in a porous medium]. Teplofizika vysokikh temperatur, 1994, vol. 32, no. 1, pp. 87-93. 39. Pitkevich V.T. et al. Fizicheskoe modelirovanie otnositel'nykh fazovykh pronitsaemostei na granitse oblasti trekhfaznoi nasyshchennosti [Physical modelling of relative phase permeabilities on the boundary of three-phase saturation zone]. Neftjanoe hozjajstvo, 2009, no. 5, pp. 70-71.

40. Pitkevich V.T. et al. Fizicheskoe modelirovanie dvuh variantov vodogazovogo vozdejstvija na obrazcah kerna [Physical modelling of relative phase permeabilities on

the boundary of three-phase saturation zone]. Neftjanoe hozjajstvo, 2010, no. 1, pp. 62-63. Evaluation \& Engineering, vol. 19, iss. 02, 2016, pp. 316-330. DOI: 10.2118/171797-PA

42. Osoba J.S., Richardson J.G., Kerver J.K., Hafford J.A., Blair P.M. Laboratory Measurements of Relative Permeability. Joumal of Petroleum Technology, 1951, vol. 3, iss. 02, pp. 47-56. DOI: 10.2118/951047-C 43. Chen A.L. and Wood A.C. Rate Effects on Water-Oil Relative Permeability. Paper SCA2001-19 presented at the 2001 Symposium of the Society of Core Analysts. Edinburgh, Scotland, 2001. Technical Conference and Exhibition, 5-8 October, New Orleans, Louisiana, 1986. DOI: 10.2118/15596-MS

45. Grattoni C., Al-Hinai S., Guise P., Fisher Q. The Role of Interstitial Water in Hydrocarbon Flow for Tight Rocks. Paper SCA2007-14 presented at the International Symposium of the Society of Core Analysts. Calgary, Canada, 2007.

\section{Библиографрический список}

1. Физико-геологические проблемы повышения нефтегазоотдачи пластов / М.Ф. Мирчинк, А.Х. Мирзаджанзаде, Ю.В. Желтов [и др.]. - М.: Недра, 1975. - 232 с.

3. ОСТ 39-235-89. Нефть. Метод определения фазовых проницаемостей в лабораторных условиях при совместной стационарной фильтрации. - М., 1989. - 29 с.

4. Михайлов А.Н. Влияние капиллярных концевых эффектов на показатели разработки // Нефтяное хозяйство. - 2003. - № 9. - С. 54-56.

5. Амикс Дж., Басс Д., Уайтинг Р. Физика нефтяного пласта: пер. с англ. - М.: Гостоптехиздат, 1962. - 572 с.

6. ОСТ 39-195-86. Нефть. Метод определения коэффициента вытеснения нефти водой в лабораторных условиях. - М., $1986 .-20$ с.

7. Михайлов Н.Н. Остаточное нефтенасыщение разрабатываемых пластов. - М.: Недра, 1992. - 270 с

8. Баренблатт Г.И., Ентов В.М., Рыжик В.М. Движение жидкостей и газов в природных пластах. - М.: Недра, $1984 .-211$ с.

9. Гуматудинов Ш.К., Ширковский А.И. Физика нефтеного и газового пласта. - М.: Недра, 1982. - 311 с.

10. Иванова М.М., Михайлов Н.Н., Яремийчук Р.С. Регулирование фильтрационных свойств пласта в околоскважинных зонах. - М.: ВНиИОЭНГ, 1988.

11. Основы технологии добычи газа / А.Х. Мирзаджанзаде, О.Л. Кузнецов, К.С. Басниев, З.С. Алиев. - М.: Недра, 2003. - 880 с.

12. Пирвердян А.М. Физика и гидравлика нефтяного пласта. - М.: Недра, 1982. - 192 с.

13. Ромм Е.С. Структурные модели порового пространства горных пород. - Л.: Недра, 1985. - 240 с.

14. Pore Geometry of Carbonate Rocksand Capillary Pressure Curves / R.L. Jodry, G.V. Cinilingarian, S.J. Mazzuiloand, H.H. Rieke // Carbonate Reservoir

Characterization: A Geologic-Engineering Analysis. Part I. - Elsevier, Amsterdam, 1992. - 670 p. DOI: 10.1016/S0376-7361(09)70129-3
15. Skopec R. A. Proper Coring and Wellsite Core Handling Procedures: The First Step Toward Rliable Core Analysis // J. Pet. Tech. - April. - 1994. - 280 p. DOI: 10.2118/28153-PA
16. Chilingarin G.V. Mazzullo S.J. Rieke H.H. Carbonate reservoir characterization: a geologic - engineerin analysis, part 2 - Elsevier, 1996. - 993 p. 16. Chilingarin G.V., Mazzullo S.J., Rieke H.H. Carbonate reservoir characterization: a geologic - engineerin analysis, part 2. - Elsevier, 1996. - 993 p. 17. Denney D. Whole Core vs. Plugs: Integrating Log and Core Data to Decrease Uncertainty in Petrophysical Interpretation and Oil-In-Place Calculations // Journal of
Petroleum Technology. - 2011. - Vol. 63. SPE. № 0811-0058-JPT. - P. 58-60. DOI: 10.2118/0811-0058-JPT

18. Herrera R. G., Fernando S.V., Hernandez F. P. On the Petrophysics of Carbonate Reservoirs Through Whole Cole Analysis // Society of Petroleum Engineers, International Petroleum Conference and Exhibition of Mexico, 10-13 October. - Veracruz, Mexico, 1994. DOI: 10.2118/28675-MS

19. Johnson N.L., Leone F.C. Statistics and experimental design. - New York - London - Sydney - Toronto, 1977. - 606 p.

20. Montgomery D.C., Peck E.A. Introduction to liner regression analysis. - New York: John Wiley \& Sons, 1982. - 504 p.

21. Watson G.S. Statistic on spheres. - New York: John Wiley and Sons, Inc., 1983. - 238 p.

22. Yarus J.M. Stochastic modeling and geostatistics // AAPG. - Tulsa, Oklahoma, 1994. - 231 p.

23. Индрупский И.М., Ястребкова К.А., Шупик Н.В. Моделирование технологических режимов работы скважин различного типа в недонасыщенных коллекторах Западной Сибири с учетом капиллярного концевого эффекта // Междунароная конференция «Тюмень - 2005. Глубокие горизонты науки и недр». - Тюмень, 2015.

24. Индрупский И.М. Учет капиллярно удерживаемой воды при моделировании двухфазной фильтрации в лабораторных ипластовых условиях // Автоматизация, телемеханизация и связь в нефтяной промышленности. - 2009. - № 11. - С. 45-53.

25. Новые принципы и технологии разработки месторождений нефти и газа. Часть 2 / С.Н. Закиров, И.М. Индрупский, Э.С. Закиров, И.С. Закиров [и др.]. М., Ижевск: Институт компьютерных исследований, 2009. - 484

26. Ястребкова К.А. Моделирование влияния капиллярных эффектов на начальную обводненность скважин в недонасыщенных пластах. - М.: ИПнГ РАН, 2014.

27. Шупик Н.В. Влияние капиллярных конщевых эффектов на работу скважин различного типа в недонасыщенных коллекторах. - М.: ИПНГ РАН, 2015.

28. Орлов Д.М., Рыжов А.Е., Перунова Т.А. Методика определения относительных фазовых проницаемостей по данным нестационарной фильтрации путем 29. Эфрос Д.А. Исследование фильтрации неоднородных систем. - М.: Гостоптехиздат, 1963. - 349 с.

29. Эфрос Д.А. Исследование фильтрации неоднородных систем. - М.: Гостоптехиздат, 1968

31. Хейфец Л.И., Неймарк А.В. Многофазные процессы в пористых средах. - М.: Химия, 1982.

31. Хейфец Л.И., Неймарк А.В. Многофазные процессы в пористых средах. - М.: Химия, 1982.

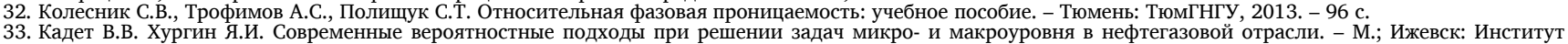
компьютерных исследований, НИЦ «Регулярная и хаотическая динамика», 2006. -240 с.

34. Лойцянский Л.Г. Механика жидкости и газа. - М.; Л.: Государственное издательство технико-теоретической литературы, 1950. - 678 с.

34. Лойцянский Л.Г. Механика жидкости и газа. - М.; Л.: Государственное издательство технико-теоретической литературы, 1950.

36. Сыртланов В.Р., Фатихов С.З. О подходе к ремасштабированию относительных фазовых проницаемостей и капиллярных кривых // Вестник ЦКР Роснедра. - 2010. - № 5. -С. 42-46.

36. Сыртланов В.Р., Фатихов С.З. О подходе к ремасштабированию относительных фазовых проницаемостей и капиллярных кривыХ $/ /$ Вестник ЦКР Рос
37. Шагапов В.Ш. О фильтрации газированной жидкости // Прикладная механика и техническая физика. - 1993. - № 5. - С. 97-106.

38. Шагапов В.Ш., Сыртланов В.Р. Фильтрация кипящей жидкости в пористой среде // Теплофизика высоких температур. - 1994. - Т. 32 , № 1. - С. 87-93.

39. Питкевич В.Т. и др. Физическое моделирование относительных фазовых проницаемостей на границе области трехфазной насьщенности // Нефтяное хозяйство. - 2009. - № 5. - С. 70-71.

40. Физическое моделирование двух вариантов водогазового воздействия на образцах керна / В.Т. Питкевич [и др.] // Нефтяное хозяйство. - 2010. - № 1. - С. 62-63.

41. Gupta R. and Maloney D.R. Intercept Method-A Novel Technique to Correct Steady-State Relative Permeability Data for Capillary End-Effects. - Society of Petroleum Engineers, 2014. DOI: 10.2118/171797-PA 43. Chen A.L. and Wood A.C. Rate Effects on Water-Oil Relative Permeability. Paper SCA2001-19 presented at the 2001 Symposium of the Society of Core Analysts. -Edinburgh, Scotland, 2001. 43. Chen A.L. and Wood A.C. Rate Effects on Water-Oil Relative Permeability. Paper SCA2001-19 presented at the 2001 Symposium of the Society of Core Analysts. - Edinburgh, Scotland, 2001. 45. The Role of Interstitial Water in Hydrocarbon Flow for Tight Rocks. Paper SCA2007-14 presented at the International Symposium of the Society of Core Analysts C. Grattoni, S. Al-Hinai, P. Guise, Q. Fisher. - Calgary, Canada, 2007. 